\title{
Pengaruh Peraturan Sekolah Terhadap Pembentukan Karakter Mahasiswa Sekolah Tinggi Theologia Jaffray Makassar
}

\author{
Reniati, Kara Elizabeth Gruber
}

\begin{abstract}
Abstrak
Tujuan penulisan ini adalah untuk mengetahui sejauh mana pengaruh peraturan sekolah terhadap pembentukan karakter mahasiswa Sekolah Tinggi Theologia Jaffray Makassar. Adapun metode yang penulis gunakan dalam penelitian ini adalah metode kuantitatif dengan cara mengumpulkan data melalui observasi lapangan, wawancara dan angket serta melalui kepustakaan yaitu melalui buku-buku yang ada diperpustakaan.

Dari hasil penelitian ini maka penulis menarik kesimpulan. Pertama, Peraturan sekolah adalah hal yang sangat baik dan memang harus ada karena dengan adanya peraturan sekolah maka itu akan menolong mahasiswa untuk dijadikan sebagai patokan yang harus diikuti. Kedua, Peraturan sekolah ketika ditaati maka itu akan berguna bagi kehidupan setiap orang dan untuk mengawasi disiplin dan tingkahlakuh sehari-hari. Ketiga, pembentukan karakter dapat dialami seseorang baik di dalam keluarga, sekolah dan masyarakat. Pembentukan karakter akan memengaruhi cara pandang terhadap diri dan lingkungannya yang tercermin lewat prilakunya sehari-hari, sebab lingkungan dimana seseorang tinggal merupakan salah satu yang dapat memengaruhi pertumbuhan karakternya. Keempat, dengan adanya peraturan sekolah khusus peraturan bagian bidang kemahasiswaan, akan memberikan pengaruh yang sangat baik kepada setiap mahasiswa yang ada di STT Jaffray Makassar, khususnya dalam pembentukan karakter kedisiplinan, tanggung jawab, kejujuran dan ketaatan.
\end{abstract}

Kata-kata Kunci: Peraturan Sekolah, Pembentukan, Karakter, Mahasiswa, Teratur.

\section{Pendahuluan}

\section{Latar Belakang Masalah}

Sekolah adalah suatu instansi atau lembaga yang menyelenggarakan pendidikan dengan berpegang pada peraturan sah yang telah ditetapkan, dan mengikuti tata cara yang telah diatur secara baik, yang bertujuan untuk membimbing dan mengajar peserta didik agar dapat mengembangkan suatu kemampuan yang dimilikinya. Menurut Monica Mayeni Manurung \& Rahmadi, dalam Jurnal Analisis Pendidikan Tinggi "Fokus utama dalam dunia pendidikan adalah manusia... dalam hal ini adalah peserta didik karena dengan adanya pendidikan, peserta didik didorong untuk terlibat dalam proses mengubah kehidupannya ke arah yang lebih baik, meningkatkan pengetahuan sehingga dapat berfungsi meningkatkan kualitas hidup pribadi dan masyarakat."1

\footnotetext{
${ }^{1}$ Monica Mayeni Manurung \& Rahmadi, "Identifikasi Faktor-faktor Pembentukan Karakter Mahasiswa," Jurnal Analisis Pendidikan Tinggi 1, No. 1 (2017): 1, diakses 08 Mei 2018, http://www.journal.fdi.or.id/index.php/jaspt/article/download/67/45/.
} 
Dalam tujuannya sebagai lembaga yang bergerak pada bidang pendidikan, sekolah membuat peraturan-peraturan yang diharapkan dapat menolong mahasiswa dalam hal kedisiplinan, sikap, dan perilaku yang baik. Aturan merupakan salah satu hal yang penting bagi kehidupan seseorang khususnya mahasiswa. Peraturan yang dibuat sekolah diharapkan dapat memberi pedoman dan ketentuan yang tidak boleh dilampaui oleh setiap peserta didik dalam berperilaku dan bertindak untuk meningkatkan perkembangan kepribadian yang baik khususnya dalam lingkungan sekolah dan masyarakat atau sosial .

Didikan selalu berkaitan erat dengan disiplin. Mary Setiawani, \& Stephen Tong menyatakan, "Disiplin mengandung arti: pengarahan akan hal-hal yang benar dan salah. Pembentukan karakter Kristen berdasarkan pondasi Alkitab sebenarnya ingin menyatakan tentang apa yang benar dan yang salah"2. Jadi semua hal yang dilakuan seharusnya didasarkan pada Alkitab. "Tugas sekolah Theologia adalah membentuk para mahasiswa supaya menjadi hamba Tuhan yang memuliakan-Nya dengan mencerminkan karakter Kristus dalam kehidupannya. Dengan pembentukan itu para mahasiswa dipersiapkan untuk menyebarkan Injil dan membimbing generasi penerus melalui perkataan, tindakan, dan sifat yang baik dan benar."3 Dalam tugasnya sebagai wadah untuk membentuk calon hamba Tuhan, sekolah berhak membuat peraturan yang dinilai mampu untuk membentuk karakter yang baik bagi mahasiswa.

Dunia pendidikan tidak terlepas dari aturan dengan tujuan untuk memberi pengajaran. Aturan itu sendiri tidaklah terlepas dari sanksi bagi yang melanggar aturan tersebut. Tujuan dari hal tesebut adalah, agar supaya peserta didik dapat mematuhi setiap peraturan yang ada, dan sanksi tersebut dimaksudkan untuk memberi pelajaran bagi pelanggar untuk tidak mengulangi perbuatan atau kelakuan yang menyalahi norma-norma yang ada. ${ }^{4}$

Namun pada kenyataannya yang terjadi di Sekolah Tinggi Theologia Jaffray Makassar, yang walaupun mahasiswa tahu bahwa akan ada sanksi ketika melanggar aturan yang sudah ditetapkan, tetapi masih ada juga yang melanggar aturan- aturan tersebut, salah satu contohnya ialah tentang ibadah kapel, yang terdapat dalam buku pedoman mahasiswa tentang kehidupan kerohanian pada poin 2. Penulis melihat hampir setiap semester selalu saja ada yang mendapat disiplin sekolah. Oleh karena itu dengan adanya peraturan sekolah besar kemungkinan mahasiswa akan lebih bisa memiliki sikap yang baik, dan lewat peraturan juga akan dilihat bagaimana pengaruhnya terhadap pembentukan karakter mahasiswa.

\section{Pokok Masalah}

Berdasarkan latar belakang di atas, maka yang menjadi pokok masalah yang akan dibahas dalam skripsi ini adalah sejauh mana pengaruh peraturan sekolah terhadap pembentukan karakter mahasiswa Sekolah Tinggi Theologia Jaffray Makassar?

\footnotetext{
${ }^{2}$ Mary Setiawani, \& Stephen Tong, Seni Membentuk Karakter Kristen (Jakarta: Lembaga Reformed Injili Indonesia, 1995), 18.

${ }^{3}$ Daniel Ronda, (ed.). Utuslah Aku: Panggilan yang Tak Lekang Oleh Waktu (Bandung: Kalam Hidup, 2012), 358.

${ }^{4}$ Samsul Hadi Rahman, "Implementasi Peraturan Sekolah Dalam Meningkatkan Kedisiplinan Guru dan Siswa” ( Tesis M. Pd, Universitas Islam Negeri Maulana Malik Ibrahim, Malang, 2016), 1, diakses 08 Mei 2018, http://etheses.uin-malang.ac.id/6096/1/14761019.pdf.
} 


\section{Tujuan Penelitian}

Bertolak dari permasalahan di atas maka tujuan yang ingin dicapai dalam penulisan karya ilmiah ini adalah:

Untuk mengetahui sejauh mana pengaruh peraturan sekolah terhadap pembentukan karakter mahasiswa Sekolah Tinggi Theologia Jaffray Makassar?

\section{Manfaat Penelitian}

Beberapa manfaat yang diharapkan dapat dicapai dalam penulisan karya ilmiah ini adalah:

Pertama, mahasiswa mengetahui pengaruh dari peraturan sekolah terhadap pembentukan karakter mahasiswa.

Kedua, Menambah pengetahuan, dan wawasan penulis dalam memahami pengaruh peraturan sekolah bagi pembentukan karakter seseorang.

Ketiga, sebagai bahan masukan kepada mahasiswa, pihak sekolah dan gereja terhadap pengaruh yang ditimbulkan dari peraturan sekolah terhadap pembentukan karakter.

Keempat, sebagai salah satu persyaratan dalam menyelesaikan studi di Sekolah Tinggi Theologia Jaffray Makassar.

\section{Metode Penelitian}

Ada pun metode yang digunakan dalam penelitian ini adalah metode kuantitatif, dengan melakukan langkah-langkah sebagai berikut:

Pertama, penelitian kepustakaan. Dalam penelitian ini penulis mengkaji buku-buku dan jurnal-jurnal yang berhubungan dengan penelitian.

Kedua, penelitian lapangan. Dalam penelitian lapangan penulis menggunakan angket dan wawancara kepada mahasiswa.

\section{Batasan Penelitian}

Dalam menguraikan tentang pengaruh peraturan sekolah terhadap pembentukan karakter mahasiswa merupakan suatu bagian yang cukup luas. Dalam artian bahwa peraturan sekolah ada banyak seperti: peraturan untuk dosen, pegawai dan peraturan untuk mahasiswa. Dalam penelitian ini, yang akan diteliti hanya difokuskan pada peraturan untuk mahasiswa. Ada pun peraturan untuk mahasiswa juga masih terbagi dalam beberapa bagian seperti: peraturan di bidang akademik, peraturan di bidang administrasi dan peraturan di bidang kemahasiswaan.

Dari peraturan itu, penulisan ini pun juga hanya mengambil fokus untuk meneliti pengaruh peraturan pada bidang kemahasiswaan khusus pada bagian peraturan umum. Adapun peraturan umum masih terbagi, tetapi penulis hanya mengambil beberapa poin penting yang paling menonjol mengapa karena peraturan ini yang sering menjadi masalah di kampus. Seperti kehidupan kerohanian, kuliah, berpacaran, cara berpakaian dan kebersihan dan pemeliharaan kampus. Dan ruang lingkup pembahasan penulisan hanya diarahkan pada pengaruh peraturan sekolah terhadap pembentukan karakter mahasiswa Sekolah Tinggi Theologia Jaffray Makassar.

Kemudian yang akan diteliti oleh penulis ialah angkatan 2014, 2015, 2016 dan 2017. Tetapi dari setiap angkatan akan diwakili oleh beberapa orang. Jadi jumlah mahasiswa yang diteliti ialah sebanyak 30 orang. 


\section{Kesimpulan}

berikut:

Pada akhir penulisan karya ilmiah ini penulis memberikan kesimpulan sebagai

Pertama, Peraturan sekolah adalah hal yang sangat baik dan memang harus ada karena dengan adanya peraturan sekolah maka itu akan menolong mahasiswa untuk dijadikan sebagai patokan yang harus diikuti.

Kedua, pembentukan karakter dapat dialami seseorang baik di dalam keluarga, sekolah dan masyarakat. Pembentukan karakter akan memengaruhi cara pandang terhadap diri dan lingkungannya yang tercermin lewat prilakunya sehari-hari, sebab lingkungan dimana seseorang tinggal merupakan salah satu yang dapat memengaruhi pertumbuhan karakternya.

Ketiga, pengaruh peraturan sekolah khususnya pada bagian bidang kemahasiswaan, dapat dilihat bahwa pengaruhnya sangat besar karena dari setiap peraturan-peraturan yang ada dapat membentuk karakter mahasiswa menjadi lebih baik seperti disiplin, bertanggung jawab, jujur, dan taat.

\section{Kepustakaan}

Astika, Made, Selviyanti Sari Bunga. "Hubungan Kompetensi Sosial Guru Kristen Terhadap Perkembangan Karakter Siswa: Tantangan Pendidikan Kristen Dalam Mencerdaskan Youth Generation.” Jurnal Jaffray 14, no. 1 (April 2016): 63-76.

Busthan, Paskalinus C. Catatan Kuliah Seminar Pendidikan Agama Kristen. Makassar: Sekolah Tinggi Theologia Jaffray, 2018. Belum dipublikasikan.

Caram, Paul G. Kekristenan Sejati. Jakarta: Voice Of Hope, 2004.

Cully, Iris V. Dinamika Pendidikan Kristen. Jakarta: BPK Gunung Mulia, 2009.

Drescher, John M. Tujuh Kebutuhan Anak. Jakarta: BPK Gunung Mulia, 2009.

Eko, Yusuf Basuki. Kristen Pemenang: Meraih Kemenangan Iman Dengan Stategi Tuhan. Yogyakarta: Garudhawaca, 2014.

Esmoda. "Penanaman Nilai-nilai Kejujuran Dalam Menyiapkan Karakter Bangsa," Jurnal Innovation 10, no. 1 (Januari-Juni 2011): 151-166, diakses 2 Agustus 2018, http:e-journal.iainjambi.ac.id/index.php/Innovation/article/download/537/501.

Fletcher, Verne H. Lihatlah Sang Manusia. Yogyakarta: Duta Wacana University Press, 1990.

Gunarsa, Singgih D. dan Yulia Singgih D. Gunarsa. Perkembangan Anak dan Remaja. Jakarta: BPK Gunung Mulia, 2011.

Gunarsa, Singgih D. dan Y. Singgih D. Gunarsa. Psikologi Praktis: Anak, Remaja dan Keluarga. Jakarta: BPK Gunung Mulia, 1993.

Gunarsa, Singgih D. Psikologi Perkembangan. Jakarta: Gunung Mulia, 1992.

Hadisubrata. Mengembangkan Kepribadian Anak Balita: Pola Pendidiksn Untuk Meletakkan Dasar Kepribadian Yang Baik. Jakarta: BPK Gunung Mulia, 1988.

Irwansa, A., Muh. Arsyad Maf'ul. "Analisis Pelaksanaan Tata Tertib Sekolah Pada Siswa di SMK Negeri 1 Makassar," Jurnal Tomalebbi II, no. 1, (2015): 1-13. Diakses 08 Mei 2018. http://ojs.unm.ac.id/tomalebbi/article/view/1670/716.

Komalasari, Kokom dan Didin Saripudin. Pendidikan Karakter. Bandung: Refika Aditama, 2017. 
Kurniasih, Imas \& Berlin Sani. Pendidikan Karakter. Jakarta: Katapena, 2017.

Kurniawan, Syamsul. Pendidikan Karakter. Yogyakarta: AR-RUZZ MEDIA, 2013.

Kusmitasari, Reni Muh. Najib Husaain, Jumrana. "Persepsi Mahasiswa Pada Sistem Layanan Sirkulasi Di UPT Perpustakaan Universitas Halu Oleo," Skripsi S. Sos, Universitas Hulu Oleo." Jurnal Ilmu Komunikasi UHO. 1, no. 3 (2016): 1-22. Diakses 20 Juni 2018.

http://ojs.uho.acid/index.php/KOMUNIKASI/search/authors/view?firstName=Reni\& middleName $=\&$ lastName $=$ Kusmitasari\&a99ffliation=Hulu\%200University\&country $=$.

Lickona, Thomas. Mendidik Untuk Membentuk Karakter: Bagaimana Sekolah Dapat Mengajarkan Sikap Hormat dan Tanggung Jawab. Jakarta: Bumi Aksra, 2012.

Linda, dan Richard Eyre. Mengajarkan Nilai-Nilai kepada Anak. Jakarta: Gramedia Pustaka Utama, 1995.

Magunwijaya, Y. B. Menumbuhkan Sikap Religius Anak-anak. Jakarta: Gramedia Pustaka Utama, 1991.

Mayeni, Monica Manurung dan Rahmadi. "Identifikasi Faktor-faktor Pembentukan

Karakter Mahasiswa.” Jurnal Analisis Pendidikan Tinggi. 1, no. 1 (2017): 1-6.

Diakses 13 Juli 2018.

http://www.journal.fdi.or.id/index.php/jaspt/article/download/67/45/.

Mulyasa, E. Manajemen Pendidikan Karakter. Jakarta: Bumi Aksara, 2014.

Mulyono, Bambang Y. Kenakalan Remaja Dalam Prespektif Pendekatan: Sosiologis-

Psikologis-Teologis dan Usaha Penanggulangannya. Yogyakarta: ANDI Offset, 1986.

Mutak, Alfius Areng. "Disiplin Rohani Sebagai Praktek Ibadah Pribadi," Jurnal Theologi Aletheia 18, no. 10 (Maret 2016): 1-24. Diakses 2 Agustus 2018. http://sttaletheia.ac.id/wp-content/uploads/2016/04/Disiplin-Rohani-Sebagai-PraktekIbadah Pribadi_Alfius-Areng-Mutak.pdf.

Nasir, Moh. Metode Penelitian. Jakarta: Ghalia Indonesia, 1988.

Nawawi, Hadari. Administrasi Sekolah. Jakarta: Ghali Indonesia, 1986.

Oswald, Sanders J. Kepemimpinan Rohani. Bandung: Kalam Hidup, 2017.

Pedoman Masuk dan Peraturan Sekolah Tinggi Theologia Jaffray Makassar. Makassar: Sekolah Tinggi Theologia Jaffray Makassar, 2014. Belum dipublikasikan.

Ronda, Daniel. (ed). Utuslah Aku: Panggilan yang Tak Lekang Oleh Waktu. Bandung: Kalam Hidup 2012.

Samani, Muchalis dan Hariyanto. Konsep dan Model Pendidikan Karakter. Bandung: Remaja Rosda karya, 2012.

Sanjaya, Wina. Penelitian Pendidikan: Jenis Metode dan Prosedur. Jakarta: Prenadamedia Group.

Setiawani, Mary., Stephen, Tong. Seni Membentuk Karakter Kristen. Jakarta: Lembaga Reformed Injili Indonesia, 1995.

Simanjuntak, Julianto \& Roswitha Ndraha. Tidak Ada Anak Yang Sulit: Mendidik Anak Dengan Sukacita dan Cinta Yang Melimpah. Tangerang: Layanan Konseling Keluarga dan Karir (LK3), 2008.

Singgih, Yulia D. Gunarsa. Asas-asas Psikologi: Keluarga Idaman. Jakarta: BPK Gunung Mulia, 2009.

Smith, Fred. Memimpin Dengan Integritas. Jakarta: Yayasan Pekabaran Injil, 2002. 
Subagyo, Andreas B. Pengantar Riset Kualitatif dan Kuantitatif. Bandung: Yayasan Kalam Hidup, 2004.

Sudjana, Nana. Tuntunan Penyususnan Karya Ilmiah. Bandung: Sinar Baru, 1988.

Sugiyono, Metode Penelitian Kuantitatif, Kualitatif, dan R\&D. Bandung: Alfabeta, 2017.

Tabrani, Rusyan A. Siswa Teladan. Jakarta: Sinergi Pustaka Indonesia, 2006.

Thalib, Bachri, Syamsul. Psikologi Pendidikan Berbasis Analisis Empiris Aplikatif. Jakarta: Kencana, 2017.

Tu'u, Tulus. Pemimpin Kristiani Yang Berhasil. Bandung: Bina Media Informasih 2010. Valentine, Barbara Hertz. Sukses Dengan Bersopan- Santun. Jakarta: Djaja Sakti, 1961.

Wijaya, Hengki (ed.). Metodologi Penelitian Pendidikan Teologi. Makassar: Sekolah Tinggi Theologia Jaffray, 2016.

Wirawan, Sarlito Sarwono. Teori-teori Psikologi Sosial. Jakarta: RajaGrafindo Persada, 2001.

Yeakley, Tom. Watak Pekerja Kristus. Bandung: Kalam Hidup, 2008.

Yuliati, Linda. Pembentukan Karakter Taat. Surabaya: Tiara Aksa, 2009.

Zubaedi. Desain Pendidikan Karakter. Jakarta: Kencana Prenada Group, 2011. . Strategi Taktis Pendidikan Karakter: Untuk PAUD dan Sekolah. Depok: Rajawali Pers, 2017. 